\title{
PAUROPODA (MYRIAPODA) RECORDS FROM HUNGARY WITH DESCRIPTION OF A NEW SPECIES
}

\author{
Ulf Scheller ${ }^{1}$, Walter P. Pfliegler ${ }^{2}$ and Zoltán Korsós ${ }^{3}$ \\ ${ }^{1}$ Häggeboholm, Häggesled, 53194 Järpås, Sweden; E-mail: ulf.scheller@telia.com \\ ${ }^{2}$ Department of Genetics and Applied Microbiology, University of Debrecen \\ H-4032 Debrecen, Egyetem tér 1, Hungary; E-mail: walterpfliegler@gmail.com \\ ${ }^{3}$ Hungarian Natural History Museum, H-1088 Budapest, Baross u. 13, Hungary \\ E-mail: korsos@nhmus.hu
}

Pauropods have been poorly studied in Hungary. Earlier records have been critically examined and a new collection has been identified. Six species belonging to the families Pauropodidae and Brachypauropodidae are reported. One species new to science is described by the first author, Donzelotauropus hungaricus sp. $\mathrm{n}$.

Key words: Myriapoda, new species, taxonomy, biogeography, soil science.

\section{INTRODUCTION}

Pauropods were shown to occur in Central Europe about one and a half decade after their discovery in London in 1866 (Luввоск 1867) by Töмösváry $(1882,1883)$ and a few years later by DADAY $(1889 a, b, 1896)$. Tömösváry also described the peculiar sensory organ of the Myriapoda named after him (Konsós 2003). The localities given in these early papers were then in the Kingdom of Hungary, presently in Romania, so strictly viewed there are no early records of any species from the current territory of Hungary. The first records appeared in the 1960s (Loкsa 1966): Allopauropus bakonyensis n. sp., Allopauropus furcula Silvestri, $A$. helophorus Remy, A. minusculus n. sp. A. minutus Silvestri, $A$. vulgaris Hansen, Decapauropus minimus n. sp., Pauropus huxleyi Lubbock, Stylopauropus dolomiticus n. sp., S. montanus n. sp., S. pedunculatus Lubbock, Scleropauropus scleroticus n. sp. and Eurypauropus latzeli Cook. These species were not described and Loksa's collection has not been refound (K. Dózsa-Farkas, pers. comm.). Loksa's new species have to be placed in nomina nuda (SCHELLER 2008) and his faunistic records of Pauropoda are difficult to evaluate.

\section{MATERIALS AND METHODS}

The first author has identified a few specimens collected in 1973 by Dr P.H. Enckell, Lund, Sweden, and a richer material collected in 2010-2011 by the second author, together giving a list of six species, all new to Hungary, one of them also new to science, Donzelotauropus hungaricus, described below by the first author. Two families are represented, Pauropodidae with five species, and Brachypauropodidae with one species. 
All the species except the new one are widely distributed in Europe or even far outside.

The specimens brought together by the second author were collected manually with a thin paintbrush and were preserved in $70 \%$ ethanol and studied in ethanol or monopropylene glycol with $1000 \times$ magnification. Individuals have been classified as adults, ad. ..., subadults, subad. ... and juveniles, juv. ..., according to the number of pairs of legs. The sex of adults and subadults was recorded.

\section{SYSTEMATICS}

\section{Family Pauropodidae Verhoeff, 1934 Genus Pauropus Lubbock, 1867}

\section{Pauropus huxleyi Lubbock, 1867}

Material. Borsod-Abaúj-Zemplén county, Bükk Mountains, Ómassa village, $48^{\circ} 06^{\prime}$ $28.5^{\prime \prime} \mathrm{N}, 20^{\circ} 31^{\prime} 51.4^{\prime \prime} \mathrm{E}$, beech forest, in leaf-litter, $500 \mathrm{~m}$ a.s.l., 1 subad. 8(ㅇ) ), November 24. 2011, W. P. Pfliegler leg.

General distribution. Palaearctic countries: Sweden, Finland, Denmark, Great Britain, Germany, Austria, Luxembourg, Switzerland, Russia, France, Portugal, Italy, Romania, Bulgaria, Slovakia, Greece, Georgia, Azerbaijan and from Natal. Reported also, but with some hesitation from Czech Republic, USA, Mexico, Australia and New Zealand.

\section{Genus Decapauropus Remy, 1931}

\section{Decapauropus cuenoti Remy, 1931}

Material. Hajdú-Bihar county, Újszentmargita, Margitai Forest, approx. $47^{\circ} 44^{\prime} 10^{\prime \prime} \mathrm{N}$ $21^{\circ} 05^{\prime} 50^{\prime \prime} \mathrm{E}$, under oaks and maples in salt-oak forest, $\sim 90 \mathrm{~m}$ a.s.l., water flotation, $1 \mathrm{ad}$. 9(ठ). 1 juv. 5, May 12, 1973, P.H. Enckell leg. Found together with the symphylans Symphylella vulgaris (Hansen) and Scolopendrellopsis subnuda (Hansen).

General distribution. The species is common in Europe, more often found in the north than in the south: Norway, Sweden, Denmark, Finland, Netherlands, Belgium, Luxembourg, Germany, Switzerland, Austria, Great Britain, France, Czech Republic, Spain, Romania, Bosnia and Herzegovina, Greece. Outside Europe it has been collected in Algeria, Morocco, Israel, Madeira, Canary Islands, Réunion and USA.

\section{Decapauropus gracilis (Hansen, 1902)}

Material. Hajdú-Bihar county, Újszentmargita, Margitai Forest, approx. $47^{\circ} 44^{\prime} 10^{\prime \prime} \mathrm{N}$, $21^{\circ} 05^{\prime} 50^{\prime \prime} \mathrm{E}$, under oaks and maples in salt-oak forest, $\sim 90 \mathrm{~m}$ a.s.l., water flotation, 2 ad. 9(ㅇ), May 12. 1973, P. H. Enckell leg.

General distribution. D. gracilis seems to have a (sub)cosmopolitan distribution. It is one of the species most often found in Europe but is also known from Africa, South Asia and the Americas. 


\section{Genus Donzelotauropus Remy, 1957}

\section{Donzelotauropus limitaneus Remy, 1962}

Material. Borsod-Abaúj-Zemplén county, Ómassa village, $48^{\circ} 06^{\prime} 28.5^{\prime \prime} \mathrm{N}, 20^{\circ} 31^{\prime} 51.4^{\prime \prime} \mathrm{E}$, beech forest, in leaf litter, 500 m a.s.l., 1 subad. 8()), October 15, 2010, 2 ad. 9()), 1 subad. 8(ㅇ), November 24. 2011, W. P. Pfliegler leg.

General distribution. D. limitaneus is a rare species known from a few localities only in Austria, Romania, Slovenia, Italy and USA. A question mark may be put at the reports from Slovenia and the USA.

\section{Donzelotauropus hungaricus Scheller sp. $\mathrm{n}$.}

$$
\text { (Figs 1-11) }
$$

Holotype. Ad. 9(ठ), Borsod-Abaúj-Zemplén county, Ómassa village, $48^{\circ} 06^{\prime} 28.5^{\prime \prime} \mathrm{N}$, $20^{\circ} 31^{\prime} 51.4^{\prime \prime} \mathrm{E}$, beech forest, in leaf litter, $500 \mathrm{~m}$ a.s.l., October 15, 2010, W. P. Pfliegler leg.

Paratypes. 1 ad. $9(ð), 1$ juv. 5, same data as holotype.

The type specimens are lodged in the collections of the Zoological Museum, University of Lund, Sweden.

Diagnosis. D. hungaricus sp. n. may be grouped together with $D$. siberiae Scheller from northeast Siberia, D. subarcticus Scheller from Alaska (both described in Scheller 1986) and D. peniculatus Hagino from Japan (Hagino 1991). It can be distinguished from them all by the shape of the antennal globulus $g$, stalk slender and capsule ovoid, not stalk thick and capsule more or less spherical, the shape of the sternite process of the collum segment, narrow and blunt, not broad with anterior incision, the pygidial setae st, short, almost rudimentary, not well developed and clavate, and the shape of the posterior margin of the anal plate, with long shallow indentation, not with two or three small ones. Other distinguishing details of the anal plate are the shape of the lateral margins, convex in D. hungaricus and D. subarcticus, concave in $D$. peniculatus and $D$. siberiae, and the shape of the posterior appendages.

Description. Adult male holotype (and adult paratype).

Length. 0.70(-0.81) mm. Head (Fig. 1). Tergal setae striate, anterior and submedian ones short clavate, posterolateral ones cylindrical; relative lengths (holotype only), 1st row: $a_{1}=a_{2}=10 ; 2$ nd row: $a_{1}=11, a_{2}=13, a_{3}=17$; 3rd row not studied; 4 th row: $a_{1}=11, a_{2}=22$, $a_{3}=17, a_{4}=14$; lateral group setae: $l_{1}=24, l_{2}=17, l_{3}=18$. Ratio $a_{1} / a_{1} a_{1}$ in 1 st row $0.6,2$ nd row $\approx 0.5$, 3rd row $=$ ?, 4 th row 0.7 . Temporal organs ovoid in tergal view, length 0.9 of shortest interdistance. Cuticle of head and temporal organs glabrous.

Antennae (Fig. 2). Segment 3 with rudimentary globulus $g^{\prime}$. Segment 4 with five thin cylindrical striate setae; their relative lengths: $p=10, p^{\prime}=(6-) 7, p^{\prime \prime}=5, r=6, u=1$. Tergal seta $p 0.8$ of the length of tergal branch $t$. The latter slightly fusiform, (3.7-)4.1 times as long as greatest diameter and about as long as sternal branch $s$, that branch 2.4 times as long 

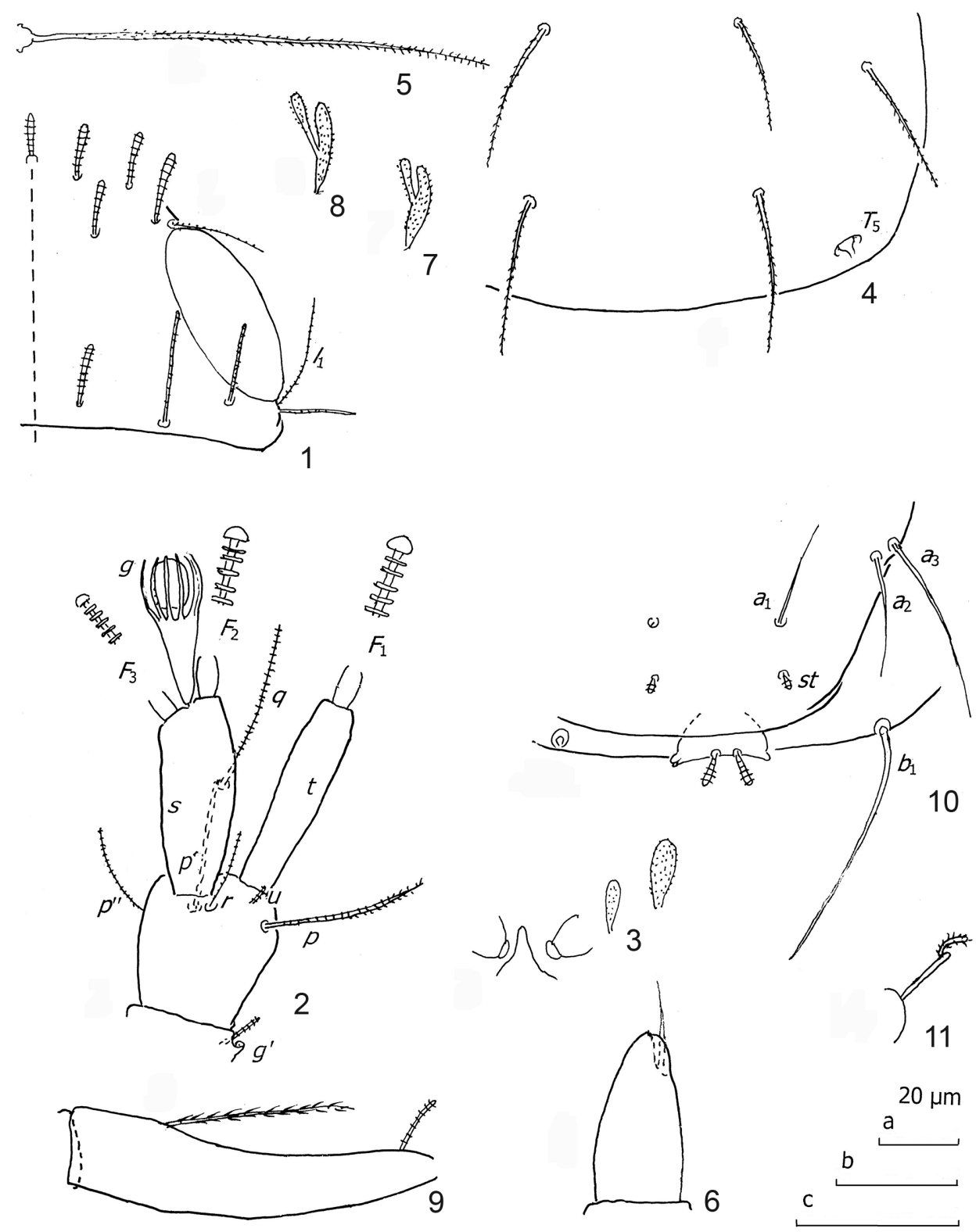

Figs 1-11. Donzelotauropus hungaricus Scheller sp. n., holotype ad.9(ð). 1 = head, median and right part, tergal view, 2 = left antenna, posterior view, $3=$ collum segment, median and left part, sternal view, $4=$ tergite VI, $5=T_{3^{\prime}} 6=$ right genital papilla, $7=$ seta on coxa of leg IX, $8=$ seta on trochanter of leg IX, $9=$ tarsus of leg IX, $10=$ pygidium, median and right part, tergal view, 11 = anal plate, lateral view. Scale a: Fig. 5; b: Figs. 1, 3, 4, 6-10; c:

Figs 2, 11. 
as greatest diameter; posterodistal corner truncate. Seta $q$ as seta $p$ of 4 th segment, 0.9 of the length of $s$. Relative lengths of flagella (basal segments included) and basal segments alone: $F_{1}=100, b s_{1}=7, F_{2}=28, b s_{2}=5, F_{3}=?, b s_{3}=7 . F_{1} 2.9$ times as long as $t, F_{2} 0.8$ of the length of s. Distal calyces helmet-shaped, distal part of flagella axes below calyces not widened. Globulus $g$ long slender, $\approx 10$ slightly curved bracts, capsule ovoid. Diameter of $g(1.1-) 1.3$ times as wide as greatest diameter of $t$. Antenna glabrous.

Trunk (Figs 3-4). Setae of collum segment (Fig. 3) folioform, shortly pubescent, may be simple. Sublateral setae 1.1 times as long as submedian ones. Sternite process blunt anteriorly, appendages barrel-shaped to conical with distinct cap; process and appendages glabrous.

Setae on anterior tergites as submedian setae of head, on posterior tergites thin pointed, shortly pubescent; $4+4$ setae on tergite I, $6+6$ on II-V, $4+2$ on VI (Fig. 4). Posterior setae on VI 0.7 of interdistance and 1.8 times as long as pygidial setae $a_{1}$.

Genital papillae (Fig. 6) with round distal part, setae 0.5 of the length of papillae.

Bothriotricha (Fig. 5). All with simple straight axes and short oblique pubescence; their relative lengths (holotype only): $T_{1}=100, T_{2}=87, T_{3}=98$ (Fig. 5), $T_{4}=127, T_{5}=$ ?.

Legs (Figs 7-9). Setae on coxa (Fig. 7) and trochanter (Fig. 8) of leg 9 furcate, shortly pubescent, main branch longish folioform, secondary branch clavate, reaching outside the tip of main branch. Tarsus of leg 9 (Fig. 9) bow-shaped tapering, 4.3(-4.7) times as long as greatest diameter. Proximal seta long thin, with oblique pubescence, $(0.4-) 0.5$ of the length of tarsus and 3.0 times as long as distal seta; the latter cylindrical striate.

Pygidium (Fig. 10). Tergum. Posterior margin rounded. Relative lengths of setae: $a_{1}=$ $10, a_{2}=11, a_{3}=17, s t=1$. $a$-setae thin pointed glabrous, st short clavate striate; $a_{1}$ directed upwards-outwards, $a_{2}$ and $a_{3}$ curved inwards, the latter also diverging. The $a_{1}$ as long as interdistance, distance $a_{1}-a_{2}$ about 5 times longer than distance $a_{2}-a_{3}$; distance st-st 10 times longer than st and as long as distance $a_{1}-a_{1}$. Cuticle glabrous.

Sternum. Posterior margin rounded. Relative lengths of setae (pygidial $a_{1}=10$ ): $b_{1}=$ $21, b_{3}=6$, both thin tapering glabrous; length of $b_{1}(0.7-) 0.8$ of interdistance, $b_{3} 0.3$ of interdistance.

Anal plate (Figs 10-11) narrowest anteriorly, broader than long, lateral margins convex, posterior margin with shallow indentation, from the median part of which two subcylindrical striate diverging appendages protrude backwards, length of appendages shorter than the length of plate (Fig. 10), pointing obliquely upwards in lateral view (Fig. 11).

\section{Family Brachypauropodidae Silvestri, 1902 Genus Brachypauropus Latzel, 1884}

\section{Brachypauropus hamiger Latzel, 1884}

Material. Borsod-Abaúj-Zemplén county, Bükk Mountains, Ómassa village, $48^{\circ} 06^{\prime} 28.5^{\prime \prime} \mathrm{N}$, $20^{\circ} 31^{\prime} 51.4^{\prime \prime}$, beech forest, in leaf-litter, $\sim 500 \mathrm{~m}$ a.s.l. 1 ad. 9(ㅇ) $), 1$ subad. 8( $\left.{ }^{\Uparrow}\right)$, October 15, 2010, W. P. Pfliegler leg.

General distribution. Not known outside Europe where it is widely distributed in the middle and southern parts, earlier known from Germany, Poland, France, Switzerland, Austria, Czech Republic, Slovakia, Bosnia and Herzegovina, Romania and Greece. 


\section{REMARKS}

The study lists six species and covers a small part only of at least many tens of species expected to live in Hungary. Like in most other areas studied the main part of the fauna seems to be build up by widespread taxa.

\section{REFERENCES}

Daday, J. (1889a) A magyarorzági Myriopodák magánrajza (Myriapoda Regni Hungariae). [Monograph of the Myriopoda in Hungary.] Királyi Magyar Természettudományi Társulat, Budapest, III+126 pp. [In Hungarian, with descriptions in Latin.]

Daday J. (1889b) Erdély faunájának százlábúi. Myriapoda Faunae Transsylvanicae. Természettudományi Füzetek 12(2-3): 85-107. [In Hungarian]

Daday, J. (1896) Classis Myriapoda. 11 Pp. In: Paszlavszky, J. (ed.): A Magyar Birodalom Állatvilága. A magyar birodalomból eddig ismert állatok rendszeres lajstroma. (Fauna Regni Hungariae). Magyar Természettudományi Társulat, Budapest. [In Hungarian and Latin]

Hagino, Y. (1991) New species of the family Pauropodidae (Pauropoda) from Central Japan. The Canadian Entomologist 123(5): 1009-1045. doi: 10.4039/Ent1231009-5

Korsós, Z. (2003) Ödön Tömösváry (1852-1884), pioneer of Hungarian myriapodology. Bulletin of the British Myriapod and Isopod Group 19: 78-87.

Latzel, R. (1884) Die Myriopoden der Österreichisch-ungarischen Monarchie. 2, Die Symphylen, Pauropoden und Diplopoden. Alfred Hölder, Wien, XII + 413 pp., 16 pls.

Loкsa, I. (1966) Die bodenzoozönologischen Verhältnisse der Flaumeichen-Buschwälder Südostmitteleuropas. Akadémiai Kiadó, Budapest, 437 pp.

Luввоск, J. (1867) On Pauropus, a new type of centipede. Transactions of the Linnean Society, London 26(3): 181-190, pl. 10; also in: Journal of the Linnean Society, London 9: 179-180.

Remy, P. A. (1962) Contribution á la connaissance de le microfaune endogée de l'Italie nord- orientale. Bulletin du Muséum national d'Histoire naturelle, Paris, ser. 2. 34(1): 72-81.

Scheller, U. (1986) Beringian Pauropoda (Myriapoda). Entomologica Scandinavica 17(3): 363-391. doi: 10.1163/187631286X00297

Scheller, U. (2008) A reclassification of Pauropoda (Myriapoda). International Journal of Myriapodology 1: 1-38. doi: 10.1163/187525408X316730

TöмösvÁry, Ö. (1882) A hazánkban elöforduló Heterognathák (Heterognatha occurring in Hungary.) Mathematikai és Természettudományi Közlemények 18: 351-365. [In Hungarian]

Töмösváry, Ö. (1883) A heterognathák egy új alakja hazánkban (A new form of Heterognatha in Hungary). Természetrajzi Füzetek 7: 39-40. [In Hungarian]

Revised version received September 23, 2014, accepted February 9, 2015, published May 29,2015 